\title{
PENGARUH KUALITAS PRODUK DAN KUALITAS PELAYANAN TERHADAP KEPUTUSAN PEMBELIAN PADA WAROENG STEAK CIPUTAT
}

\author{
Arif Siaha Widodo, Sheila Ardilla Yughi, Arsid \\ Assiten Ahli Fakultas Ekonomi Universitas Pamulang \\ email :dosen01725@unpam.ac.id, dosen01719@unpam.ac.id, \\ dosen00496@unpam.ac.id
}

\begin{abstract}
ABSTRAK
Penelitian ini bertujuan untuk mengetahui kualitas produk dan kualitas pelayanan terhadap keputusan pembelian pada Warong Steak Ciputat. Metode penelitian yang digunakan adalah metode kuantitatif selanjutnya dianalisis menggunakan uji validitas dan reliabilitas, uji asumsi klasik, analisis regresi berganda, korelasi, dan uji hipotesis dengan menggunakan SPSS. Jumlah responden sebanyak 100 sampel pelanggan dari Waroeng Steak Ciputat. Hasil penelitian menunjukkan bahwa terdapat pengaruh yang positif dan signifikan secara parsial antara kualitas produk terhadap keputusan pembelian dengan nilai $\mathrm{t}$ hitung $>\mathrm{t}$ tabel $(5,757>1.660)$ dan nilai signifikan $0,000<0,05$. Terdapat pengaruh yang positif dan signifikan secara parsial antara kualitas produk terhadap keputusan pembelian dengan nilai t hitung $>\mathrm{t}$ tabel $(5,214>1.660)$ dan nilai signifikan $0,000<0,05$. Selanjutnya pada uji $\mathrm{F}$ diperoleh nilai $\mathrm{F}$ hitung $>$ tabel $(20,777>3,09)$ yang artinya secara bersama sama antara variabel kulitas produk dan kualitas pelayanan terhadap keputusan pembelian dapat terima.
\end{abstract}

Kata Kunci: Kualitas produk; kualitas pelayanan; keputusan pembelian.

\section{ABSTRACT}

This study aims to determine product quality and service quality on purchasing decisions at Warong Steak Ciputat. The research method used is a quantitative method which is then analyzed using validity and reliability tests, classical assumption tests, multiple regression analysis, correlations, and hypothesis testing using SPSS. The number of respondents is 100 samples of customers from Waroeng Steak Ciputat. The results showed that there was a positive and partially significant effect between product quality on purchasing decisions with a t count $>t$ table $(5.757>1.660)$ and a significant value of $0.000<0.05$. There is a positive and partially significant effect between product quality on purchasing decisions with a t count $>t$ table $(5.214>1.660)$ and a significant value of $0.000<0.05$. Furthermore, in the F test, the calculated $F$ value $>$ table $(20.777>3.09)$ which means that the product quality and service quality variables on purchasing decisions are acceptable.

Keywords: Product quality; service quality; buying decision.

\section{I.PENDAHULUAN}

\subsection{Latar Belakang}

Setiap perusahaan dituntut untuk menciptakan strategi bersaing yang baik dan terpadu karena persaingan adalah kunci dari keberhasilan atau kegagalan suatu perusahaan. Meningkatnya intensitas persaingan dari pesaing menuntut perusahaan untuk selalu memperhatikan kebutuhan dan keinginan konsumen serta berusaha memenuhi harapan 
konsumen dengan cara memberikan pelayanan yang lebih memuaskan daripada yang dilakukan oleh pesaing. Dengan demikian, hanya perusahaan yang berkualitas yang dapat bersaing dan menguasai pasar. Di samping itu, banyaknya usaha bermunculan baik perusahaan kecil maupun besar berdampak pada persaingan yang ketat antar perusahaan, terutama persaingan yang berasal dari perusahaan sejenis. Hal ini menyebabkan perusahaan yang menerapkan konsep pemasaran perlu mencermati perilaku konsumen dan faktor-faktor yang mempengaruhi keputusan pembeliannya dalam usaha-usaha pemasaran sebuah produk yang dilalukan. Hal tersebut dikarenakan dalam konsep pemasaran, salah satu cara untuk mencapai tujuan perusahaan adalah dengan mengetahui apa kebutuhan dan keinginan konsumen atau pasar sasaran serta memberikan kepuasan yang diharapkan secara lebih efektif dan efisien dibandingkan para pesaing.

Salah satu yang dianggap cukup ramai dalam persaingan yang semakin ketat ini adalah industri retail. Retail adalah usaha yang menjual produk / dagangan mengenai kebutuhan pokok manusia seperti makanan yang ada pada perusahaan Waroeng Steak Ciputat, yang mengunakan sistem modern dan manual (modern yaitu dengan mengunnakan debit dan sebagainya dan manual yaitu menggunkan pramuniaga yang melayani). Industri retail di Indonesia dapat dibedakan menjadi 2 kelompok besar, yakni Ritel Tradisional dan Retail Modern. Retail modern merupakan pengembangan dari retail tradisional. Format retail ini muncul dan berkembang seiring perkembangan perekonomian, teknologi, dan gaya hidup masyarakat yang membuat masyarakat menuntut kenyamanan yang lebih dalam berbelanja. Restauran merupakan jenis bisnis retail yang sedang berkembang pesat saat ini menjual produk kebutuhan sehari-hari manusia yaitu makanan dan menawarkan kemudahan karena lokasi atau letaknya yang bisa dijangkau dan dekat dengan konsumen serta mengutamakan kepraktisan dan kecepatan yang didukung dari luas area restaurant sehingga konsumen merasa nyaman untuk beristirahat makan dan ataupun dibawa pulang makanan yang telah ia beli. Keuntungan lain berbelanja di Waroeng steak ini adalah suasana aman dan yaman dalam berbelanja, tidak kesulitan memilih makanan yang diinginkan karena banyaknya pilihan-pilihan menu yang tersedia, harga produk pasti sehingga tidak perlu ditawar dan dapat berbelanja makanan tinggal memilih berapa yang pas dikantong pelanggan dan atau disukai pelanggan. dan harganyan cukup cocok buat para remaja yang ingin menikmati daging steak tapi dengan harga yang cukup murah.

Waroeng Steak Ciputat sebagai salah satu perusahaan industri ritel yang berupa Restaurant Steak dan makanan lain yang berupa daging ayam dan ikan, serta termasuk perusahaan nasional yang berada di Indonesia yang menyediakan makanan untuk keperluan sehari hari yaitu asupan nutrisi. Segala upaya dalam peningkatan kualitas pelayanan dilakukan oleh Waroeng Steak Ciputat untuk dapat bersaing dengan restaurant steak lainya meliputi lokasi yang strategis, pelayanan yang baik, tempat yang nyaman, dan inovasi terhadap 
produk, harga yang cocok bagi kalangan remaja, dan Waroeng Steak Ciputat berusaha untuk memberikan kualitas pelayanan yang terbaik bagi pelanggannya. Keputusan pembelian merupakan tahap dalam akhir proses pengambilan keputusan pembelian sampai konsumen benar benar membeli produk atau jasa (Sangadji, 2013). Ada berbagai macam faktor faktor yang dapat menjadi sebuah pertimbangan konsumen untuk mengambil keputusan pembelian.Diantaranya merupakan faktor kualitas produk dan kualitas pelayanan yang coba ditawarkan oleh Waroeng Steak Ciputat dimaksudkan untuk menciptakan Brand Image yang baik ke pelanggannya/konsumen sehingga konsumen akan melakukan keputusan pembelian atas produk pada Waroeng Steak tersebut.

Waroeng Steak Ciputat menghadapi faktor persoalan kendala dalam segi kualitas pelayanan dan kualitas produk, salah satu dari faktor-faktor tersebut dari segi kecepatan dan ketepatan waktu yang telah diterapkan SOP (Standar Operasional Perusahaan) untuk meminimalisir efisiensi waktu untuk mencegah hal dalam antrian panjang, komplain waktu yang tidak sesuai dengan ketepatan yang telah dipesan. Meskipun demikian terkadang pelayanan yang diberikan belum tentu sesuai dengan harapan konsumen. Misalnya saja dengan marah-marah. Biasanya komplain diberikan ketika kecewa atau bahkan merasa dirugikan dengan pelayanan yang telah diberikan. Sehingga tak heran bila sebagian konsumen mengeluh dengan pelayanan yang diberikan dan menyampaikan komplainnya dengan cara yang kurang sopan. Biasanya komplain diberikan ketika kecewa atau bahkan merasa dirugikan dengan pelayanan yang telah diberikan. Adapun data komplain yang terjadi selama periode tiga tahun terakhir dapat dilihat pada tabel 1.1 berikut.

Tabel 1.1

Data Komplain Waroeng Steak Ciputat Tahun 2018-2020

\begin{tabular}{|c|c|c|c|c|}
\hline \multirow{3}{*}{ Tahun } & & & & \multirow{3}{*}{$\begin{array}{l}\text { Jumlah } \\
\text { Keluhan } \\
\text { Konsumen } \\
\text { (orang) }\end{array}$} \\
\hline & \multicolumn{3}{|c|}{ Jenis Keluhan } & \\
\hline & $\begin{array}{l}\text { Pelayanara } \\
\text { Kurang } \\
\text { Cepat }\end{array}$ & $\begin{array}{l}\text { Kebersihan } \\
\text { yang Kurang } \\
\text { Diperhatikan }\end{array}$ & $\begin{array}{l}\text { Kualitas } \\
\text { Produk } \\
\text { Kurang } \\
\text { Baik } \\
\end{array}$ & \\
\hline 2018 & 49 & 40 & 35 & 24 \\
\hline 2019 & 78 & 53 & 56 & 87 \\
\hline 2020 & 66 & 55 & 80 & 201 \\
\hline
\end{tabular}

Sumber: data primer, 2021

Berdasarkan tabel 1.1 dapat di lihat dari keefektifan atau sikap emosional pembeli berdasarkan data komplain dari tahun ke tahun dalam menentukan kepuasan konsumen sehingga dapat di lihat bahwa Waroeng Steak sendiri mengalami pasang surut persaingan bisnis yang dilihat dari persaingan yang semakin ketat serta inovasi beragam yang di lakukan para pesaing baik dalam sistem penjualan produk maupun sistem pelayanan dalam mencapai kepuasan pelanggan. Kekecewaan yang diterima oleh konsumen akan menimbulkan ketidakpuasan konsumen. Kualitas Pelayanan adalah permulaan dari kepuasan konsumen. Konsumen merasa puas apabila mereka memperoleh pelayanan yang baik atau sesuai dengan yang diharapkan. Waroeng Steak Ciputat harus segera mengatasi masalah ini meskipun masalah ini kelihatan sepele. Menurut Kotler dan Amstrong (2012:583) kualitas produk dan kualitas pelayanan berpengaruh terhadap kepuasan konsumen, selain itu juga berpengaruh menciptakan keuntungan badan usaha. 
Berdasarkan hal tersebut peneliti tertarik melakukan penelitian dengan tujuan untuk mengetahui apakah terdapat pengaruh baik secara parsial maupun secara simultan kualitas produk dan kualitas pelayanan terhadap keputusan pembelian konsumen pada restauran Waroeng Steak di Ciputat.

\subsection{Perumusan Masalah}

Perumusan masalah penelitian sebagai berikut:

1. Apakah Kualitas Produk berpengaruh signifikan terhadap Keputusan Pembelian pada Waroeng Steak Ciputat secara parsial?

2. Apakah Kualitas Pelayanan berpengaruh signifikan secara parsial terhadap Keputusan Pembelian pada Waroeng Steak Ciputat secara parsial?

3. Apakah Kualitas Produk dan Kualias Pelayanan berpengaruh signifikan terhadap

Keputusan Pembelian pada Waroeng Steak Ciputat secara simultan?

\subsection{Tujuan Penelitian}

Tujuan penelitian sebagai berikut:

1. Untuk mengetahui pengaruh Kualitas Produk terhadap Keputusan Pembelian pada Waroeng Steak Ciputat secara parsial.

2. Untuk mengetahui pengaruh Kualitas Pelayanan terhadap Keputusan Pembelian pada Waroeng Steak Ciputat secara parsial.

3. Untuk mengetahui pengaruh Kualitas Produk Dan Kualitas Pelayanan terhadap keputusan pembelian pada Waroeng Steak Ciputat secara simultan.

\section{TINJAUAN PUSTAKA}

2.1 Kualitas Produk
Menurut Kotler dan Amstrong (2012:299) berpendapat “ kualitas produk adalah kemampuan produk untuk menampilkan fungsinya, hal ini termasuk kegunaan dari produk, keandalan, kemudahan dalam penggunaan dan perbaikan ,dan nilai -nilai yang lainya, kualitas produk dapat di tinjau dari dua sudut pandang pemasaran kualitas diukur dengan persepsi pembeli ,maka sudut pandang yang digunakan untuk melihat kualitas produk adalah sudut pandang eksternal. Menurut Fandy Tjiptono (2012:32) mengatakan bahwa" kualitas adalah suatu kondisi ysng dinamis yang berhubungan dengan produk, jasa, manusia, proses, lingkungan yang memenuhi atau melebihi harapan". Dari beberapa pendapat tersebut dapat disimpulkan bahwa kualitas produk merupakan kondisi dinamis yang berhubungan dengan produk, manusia atau tenaga kerja, proses, dan tugas serta lingkungan yang memenuhi atau melebihi harapan pelanggan atau konsumen.

Menurut Kotler dan Amstrong (2012:349) menjelaskan bahwa didalam memusakan pelanggan, ada beberapa indikator kualitas produk yaitu :

a. Kinerja (performance)

Kinerja produk merupakan indikator paling dasar dari produk tersebut. Pelanggan akan kecewa jika kinerja produk tersebut tidak dapat memenuhi harapan mereka.

b. Daya Tahan (durability)

Dimensi kualitas produk yang menunjuaka berapa lama umur produk bersangkutan bertahan sebelum produk tersebut harus diganti. Dengan semakin besar frekuensi pemakaian konnsumen terhadap produk tersebut, maka semakin besar pula daya tahan produk.

c. Kesesuaian ( conformance)

Indikator kualitas produk yang sejauh mana karakteristeak operasi dasar dari sebuah produk memenuhi 
spesifakasi tertentu dari konsumen atau tidak ditemukanya cacat pada produk tersebut.

d. Fitur (features)

Karakteristeak produk yang dirancang untuk menyempurnakan fungsi produk atau menambah fungsi dasar, berkaitan dengan pilihan-pilihan produk dan pengembanganya. Sehingga akan menambah keterkaqitan konsumen atau pelanggan terhadap produk tersebut.

e. Reliabilitas (reliabilit)

Yaitu probabilitas bahwa produk akan bekerja dengan memuaskan atau tidak dalam periode waktu tertentu. Semakin kemungkinan terjadinya kerusakan maka produk tersebut dapat diandalkan. Dimensi kualitas produk ini penting karena berhubungan dengan kepuasan konsumen.

f. Estetika (aesthetics)

Merupakan karakteristeak yang bersifat subjektif mengenai nilai-nilai estetika yang berkaitan dengan penilaian pribadi dan preferensi dari setiap individu. Dapat berupa penampilan produk bisa dilihat dari tampak, rasa, bau, dan bentuk dari produk, atau daya tarik produk terhadap panca indra. Misalnya, bentuk fisik mobil yang menarik, model atau bentuk desain yang artistic,warna, dan sebagainya.

\subsection{Kualitas Pelayanan}

Pada dasarnya kualitas pelayanan berfokus pada upaya pemenuhan kebutuhan dan keinginan pelanggan serta ketepatan penyampaiannya untuk mengimbangi harapan pelanggan meurut Kotler (2010: 83) kualitas pelayanan adalah segala bentuk aktivitas yang dilakukan perusahaan untuk memenuhi harapan konsumen. Menurut Wyckof dalam Fandy Tjiptono (2014:268), kualitas pelayanan adalah tinggkat keunggulan (excellence) yang diharapkan dengan kata lain ,terdapat dua faktor utama yang mempengaruhi kualitas pelanggan yaitu jasa yang diharapkan (expected service) dan jasa yang dipersepsikan (perceived service). Sedangkan menurut Gronroos dalam Fandy Tjiptono (2014:268), kualitas pelayanan yang di presepsikan pelanggan terdiri atas dua dimensi utama .dimensi pertama yaitu technical quality yang berkaitan dengan kualitas output pelayanan yang dipresepsikan pelanggan . Komponen ini dapat dijabarkan lagi menjadi tiga jenis yaitu search quality atau dapat di evaluasi sebelum di beli , experience quality atau hanya bisa dievaluasi setelah dikonsumsi, dan credence quality atau sukar dievaluasi pelanggan sekalipun telah mengkomsumsi jasa. Dimemsi kedua yaitu functional quality yang berkaitan dengan kualitas cara penyampaian jasa atau menyangkut proses transfer kualitas teknis, output atau hasil akhir jasa dari penyedia jasa ke pelanggan.

Menurut Kotler (2015:134) dimensi kualitas pelayanan jasa meliputi kehandalan (reliability), daya tanggkap (responsiveness), empati (empathy), jaminan (assurance), berwujud (tangible). Adapun penjelasanya menurut RW. Suparyanto dan Rosad (2105:134) adalah sebagai berikut :

\section{a. Kehandalan (reliability)}

Yaitu kemampuan prusahaan untuk memberikan jasa sesuai dengan yang dijanjikan secara akurat dan terpercaya. Kehandalan antara lain ditujukan dengan ketetapan waktu, pelayanan yang sama untuk semua pelanggan tanpa kesalahan, sikap simpatik, dan tinggat akurasii tinggi

b. Ketanggapan responsiveness)

Suatu kebijakan untuk membantu dan memberikan jasa yang cepat (responsif), dan tepat kepada pelanggan, dengan 
penyampaian informasi yang jelas.

\section{c. Empati (empathy)}

Yaitu memberikan perhatian yang tulus bersifat pribadi yang diberikan kepada para pelanggan berupaya memahami keinginan pelanggan, memahami keluhan setiap pelanggan ,mengetahui identitas pribadi pelanggan dan memanfaatkanya untuk memberikan pelayanan terbaik yang memuaskan kepada setiap pelanggan.

\section{d. Jaminan (assurance)}

Yaitu jaminan pengetahuan, kemampuan, kesopanan, dan sikap dipercaya yang dimiliki karyawan. Hal ini meliputi beberapa komponen antara lain komunikasi, kredibilitas, keamanan dan kompetensi.

e. Berwujud (tangible)

Yaitu kemampuan suatu perusahaan dalam menunjukan eksistensi bukti fisik kepada pihak eksternal. Bukti fisik ini antara lain gedung, mesin, peralatan, teknologi, lahan parkir, kebersihan, serta penampilan pegawai.

\subsection{Keputusan Pembelian}

Menurut Kotler (2010) keputusan pembelian adalah tindakan dari konsumen untuk mau membeli atau tidak terhadap produk dari berbagai faktor yang mempengaruhi konsumen dalam melakukan pembelian suatau produk atau jasa sedangkan menurut Schiffman dan Kanuk dalam Sumarwan (2015:357) mendefinisikan suatu keputusan sebagai suatu tindakan dari dua atau lebih pilihan alternatif. Seorang konsumen yang hendak melakukan pilihan maka ia harus memiliki pilihan alternatif. Setiadi dalam Sangadji dalam Sopiah (2013:121) mendefinisikan bahwa inti dari pengambilan keputusan konsumen adalah proses pengintegrasian yang mengombinasikan pengetahuan untuk mengevaluasi dua prilaku alternatif atau lebih, dan memiliki salah satu di antaranya. Hasil dari proses pengintegrasian ini adalah suatu pilihan yang disajikan secara kognitif sebagai keinginan berperilaku. Jadi, kesimpulanya adalah proses dimana konsumen mulai mengidentifikasi semua pilihan alternative baik itu kualiotas produk maupun harga, setelah itu dapat diputuskan dalam mengambil keputusan pembelian.

Indikator keputusan pembelian menurut Kotler (2007-222) dalam Nopriani (2016:6) yaitu :

a. Kemantapan pada sebuah produk adalah kualitas produk yang sangat baik akan membangun kepercayaan konsumen sehingga merupakan penunjang kepuasan konsumen

b. Kebiasaan dalam membeli adalah pengulangan suatu secara terusmenerus dalam melakukan pembelian produk yang sama.

c. Memberi rekomendasi kepada orang lain adalah memberikan kepada seseorang atau lebih bahwa sesuatu yang dapat dipercaya, dapat juga merekomendasi diartikan sebagai menyarankan, mengajak untuk bergabung, menganjurkan suatu perintah.

d. Melakukan pembelian ulang. Pengertian pembelian ulang adalah individu melakukan pembelian produk atau jasa yang menentukan untuk membeli lagi, maka pembelian kedua dan selanjutnya disebut pembelian berulang.

\subsection{Kerangka Pemikiran}

Penelitian ini menggunakan Kualitas Produk Dan Kualitas Pelayanan sebagai variabel independen, serta Keputusan Pembelian sebagai variabel dependen, 
adapun kerangka berpikir dari penelitian ini yaitu:

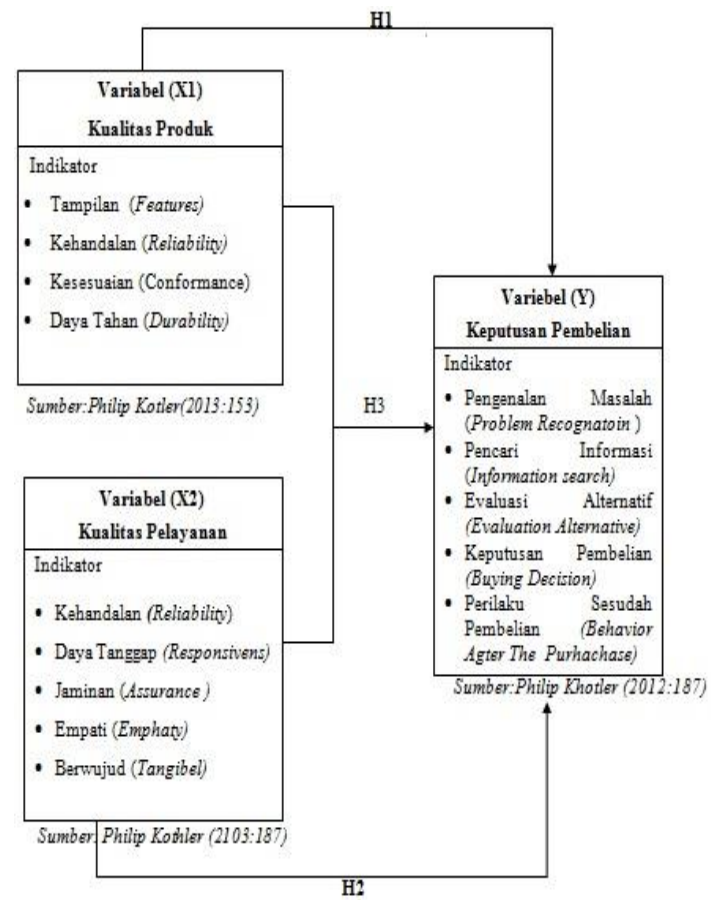

Gambar 2. Kerangka Berfikir

\section{METODOLOGI PENELITIAN}

\subsection{Rancangan Penelitian}

Mengacu pada penelitian Amrullah, Siburian S., P., \& Zainurossalami (2016) yang menganalisis pengaruh kualitas produk dan kualitas layanan terhadap keputusan pembelian sepeda motor Honda dan metode yang digunakan adalah data kuantitatif dengan data primer dengan pendekatan penelitian deskriptif.

\subsection{Variabel dan pengukuran}

Menurut Sugiyono (2012:64) "Variabel penelitian adalah suatu atribut atau sifat atau nilai dari orang, obyek atau kegiatan yang mempunyai variabel tertentu yang ditetapkan oleh penelitian untuk dipelajari ditarik kesimpulanya". Dalam penelitian ini terdapat tiga jenis variabel, yaitu variabel in dependen kualitas produk (X1) kualitas pelayanan (X2) dan dependen Keputusan pembelian (Y) pada Waroeng Steak
Ciputat, dapat dijelaskan sebagai berikut

a. Kualitas produk menggambarkan sesutau barang atau jenis yang ditawarkan kepada pengunjung waroeng steak untuk memenuhi kebutuhan yang di belinya.

b. Kualitas pelayanan menggambarkan pelayanan yang didapat oleh pengunjung waroeng steak untuk memenuhi kebutuhan produk yang dibelinya ataupun saat menghadapi permasalahan dengan produk layanan tersebut.

c. Keputusan pembelian dalam penelitian ini adalah evaluasi dan keseluruhan kinerja yang diberikan perusahaan dalam memberikan pelayanan, memenuhi harapan dan keinginan pengunjung.

d.

Tabel 3.2

Operasional Variabel Penelitian

Kualitas Produk dan Kualitas

Pelayanan Terhadap Keputusan Pembelian

\section{Definisi \\ Operasional}

Indikator

Kualitas Produk 1. Features (Tampilan)

(X1) menurut 2. Reliability

Kotler dan (kehandalan)

Amstrong 3. Conformance

(2014:248) (Kesesuaia)n)

Produk adalah 4. Durability (Daya

segala sesuatu Tahan)

yang dapat (Philip Kotler

ditawarkan ke (2013:153)

pasar agar dapat

memuaskan

sesuatu keinginan

atau kebutuhan 


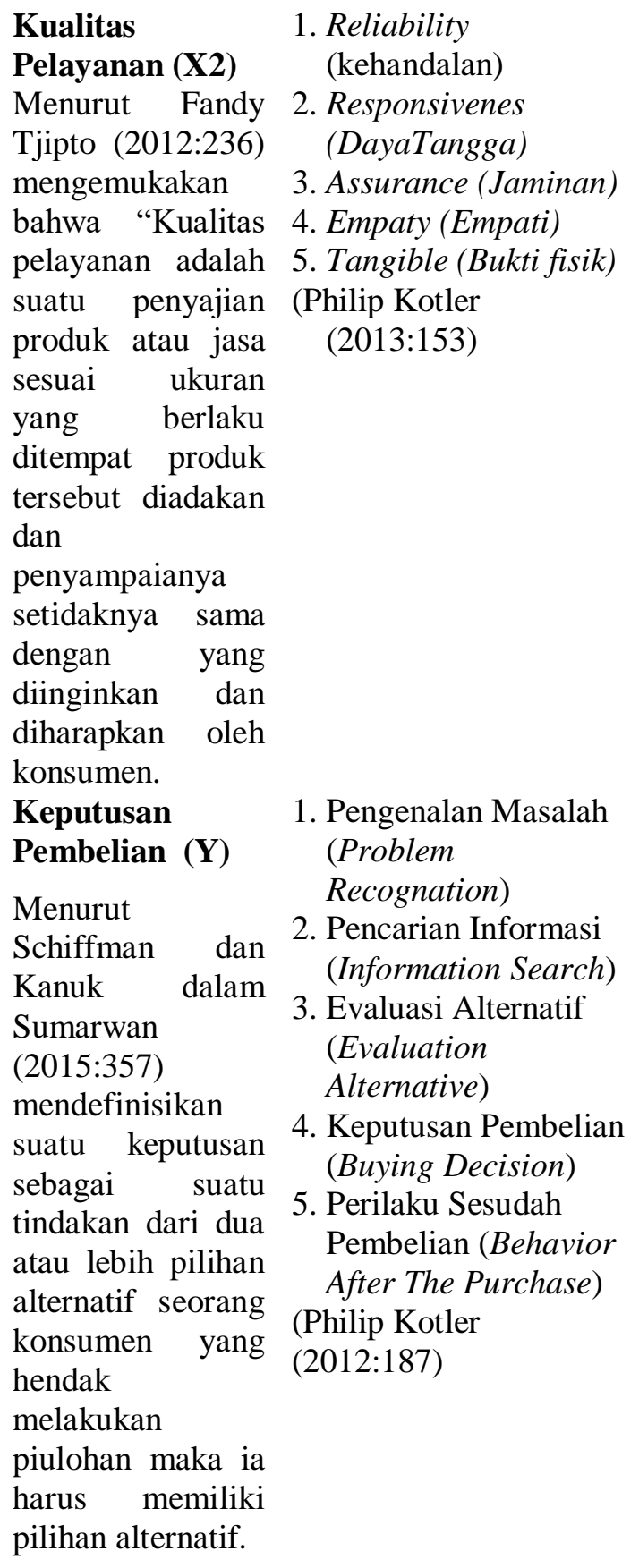

\subsection{Populasi dan Sampel Penelitian}

Dalam penelitian ini yang dijadikan populasi adalah pengunjung Waroeng Steak Ciputat yang menjadi pengunjung dari bulan Desember 2020 Maret 2021.
Teknik sampling yang digunakan dalam penelitian ini adalah teknik insidential sampling yakni teknik pengambilan anggota sampel dengan berdasarkan kebetulan, siapa saja yang kebetulan ditemukan peneliti dapat diambil sebagai sampel bila dianggap sesuai sebagai sumber data. Didalam penelitian ini sampel yang diambil secara kebetulan dan sesuai dengan rumus slovin adalah :

$$
\begin{aligned}
& \mathrm{n}=+\frac{N}{N(e)+1} \\
& \mathrm{n}=\frac{6.032}{6.032(0,1)^{2}+1} \\
& \mathrm{n}=\frac{6.032}{6.032(0,01)+1} \\
& \mathrm{n}=\frac{6.032}{60,32+1} \\
& \mathrm{n}=\frac{6.032}{61,32}=100
\end{aligned}
$$

Dari hasil perhitungan dengan menggunakan rumus diatas, maka sampel atau responden yang digunakan dalam penelitian ini berjumlah 100 responden.

\subsection{Metode Pengumpulan Data}

Data yang digunakan dalam penelitian ini merupakan data primer dan data sekunder. Pengumpulan data pada penelitian ini dengan cara kuesioner, skala likert dan studi pustaka.

\subsection{Metode Analisis Data}

\subsubsection{Uji Validitas Data}

Dalam penelitian ini, untuk mengolah dan menganalisis uji validitas peneliti menggunakan korelasi Product Moment yaitu dengan mengkorelasikan skor item dengan skor total sehingga diperoleh nilai $r$ hitung kemudian dibandingkan dengan $\mathrm{r}$ tabel. Taraf signifikansi $\alpha=0,5$ atau (5\%), artinya tingkat kepercayaan pengujiannya adalah $95 \%$. Untuk menghitung tingkat validitasnya dilakukan dengan menggunakan alat bantu program Statistical Package for Social Science (SPSS) for window versi 23. Keputusan 
suatu instrument dikatakan valid dan tidaknya menurut Sugiyono (2016:133134) yaitu "dengan membandingkan antara $r$ hitung dengan $r$ tabel dengan ketentuan" :

(a) Jika $\mathrm{r}$ hitung > $\mathrm{r}$ tabel, maka instrument valid.

(b) Jika $\mathrm{r}$ hitung $<\mathrm{r}$ tabel, maka dikatakan tidak valid

\subsubsection{Uji Realibilitas Data}

Untuk menghitung tingkat reliabilitasnya dilakukan dengan menggunakan software alat bantu program Statistical Package for Social Science (SPSS) for window versi 23. Menurut Arikunto (2012:224) untuk menentukan reliable tidaknya instrumen dilakukan dengan cara membandingkan nilai r Alpha (Cronbach Alpha) dengan $\mathrm{r}$ tabel yang sudah di ketahui pada uji validitas yaitu :

a). Jika r Alpha positif atau r Alpha $>\mathrm{r}$ tabel, maka instrumen tersebut handal (reliable).

b). Jika r Alpha negatif atau r Alpha< dari $\mathrm{r}$ tabel, maka instrumen tersebut tidak handal (not reliable)

\subsubsection{Uji Asumsi Klasik}

Uji Asumsi Klasik digunakan untuk mengetahui ketepatan data.

\section{Uji Normalitas}

Uji Normalitas adalah sebuah uji yang dilakukan dengan tujuan untuk menilai sebaran data pada sebuah kelompok data atau variabel, apakah sebaran data tersebut berdistribusi normal ataukah tidak. Dari beberapa metode uji normalitas penelitian ini menggunakan salah satunya yaitu metode grafik yang merupakan uji normalitas residual dengan melihat penyebaran data pada sumber diagonal pada grafik normal P-P Plot of regression standardized residual. Sebagai dasar pengambilan keputusannya, jika titik-titik menyebar sekitar garis dan mengikuti garis diagonal, maka nilai residual tersebut telah normal.

\section{Uji Multikolinearitas}

Pengujian ada tidaknya multikolinearitas dapat dilakukan dengan melihat nilai koefisien korelasinya. Untuk bisa diktakan tidak ada multikolinearitas nilai koefisien korelasinya $<0,75$ atau sama dengan nilai VIF $\geq 10$ (variance inflation factor) dan nilai tolerance.

\section{Uji Heteroskedastisitas}

Uji Heteroskedastisitas merupakan salah satu bagian dari uji asumsi klasik model regresi. Untuk mendeteksi ada tidaknya heteroskedastisitas dalam sebuah data, peneliti melakukan cara Uji Glejser. Model regresi yang baik seharusnya tidak terjadi heteroskedastisitas. Dasar pengambilan keputusan pada Uji Heteroskedastisitas yaitu :

a. Jika nilai signifakasi lebih besar dari 0,05, kesimpulannya adalah tidak terjadi heteroskedastisitas.

b. Jika nilai signifakasi lebih kecil dari 0,05 , kesimpulannya adalah terjadi heteroskedastisitas.

\subsubsection{Analisis Regresi Linier Berganda}

Persamaan umum regresi berganda menurut Sugiyono (2013:277) adalah:

$$
y=\alpha+\beta_{1} x_{1}+\beta_{2} x_{2}+\varepsilon
$$

Dimana :

$\mathrm{y}=$ Keputusan Pembelian

$\alpha=$ Konstanta, merupakan nilai terkait yang dalam hal ini adalah y pada saat variabel bebasnya adalah $0\left(\mathrm{x}_{1}, \mathrm{x}_{2}=0\right)$

$\beta_{1}=$ Koefisien regresi berganda antar variabel bebas $\mathrm{x}_{1}$ terhadap variabel terikat $\mathrm{y}$, bila variabel bebas $\mathrm{x}_{2}$ dianggap konstan

$\beta_{2}=$ Koefisien regresi berganda antar variabel bebas $\mathrm{x}_{2}$ terhadap variabel terikat $\mathrm{y}$, bila variabel bebas $\mathrm{x}_{1}$ diangggap konstan

$\mathrm{X}_{1}=$ Kualitas Produk

$\mathrm{X}_{2}=$ Kualitas Pelayanan

$\varepsilon=$ Faktor-faktor lain yang

mempengaruhi variabel

\subsubsection{Uji Koefesien Korelasi Product} Moment

Koefeisen korelasi berganda merupakan ukuran keeratan hubungan 
antara variabel terikat dan semua variabel bebas. Hubungan antara variabel $(\mathrm{X})$ dengan variabel $(\mathrm{Y})$ dapat bersifat :

a. Positif, artinya jika variabel bebas (X) turun maka variabel terikat (Y) naik.

b. Negative, artinya jika variabel bebas (X) turun maka variabel terikat (Y) turun.

Dengan dasar pengambilan keputusan berdasarkan perbandingan sig. dengan $\mathrm{a}=10 \%(0,10)$ :

1. Jika sig. < 0,10, maka korelasi

2. Jika sig. $>0,10$, maka tidak korelasi.

\subsubsection{Analisis Koefisien Korelasi Pearson} (r)

Untuk mengetahui bagaimana hubungan antara kualitas produk dan kualitas pelayanan dengan keputusan pembelian dilakukan dengan menggunakan software alat bantu program Statistical Package for Social Science (SPSS) for windows versi 23. Dengan ketentuan sebagai berikut :

a. Apabila nilai $\mathrm{r}>0$, maka hubungan antara $\mathrm{X}$ dan $\mathrm{Y}$ merupakan hubungan yang positif yaitu semakin besar nilai variabel $\mathrm{X}$ (bebas), maka semakin besar pula pengaruh terhadap nilai variabel $\mathrm{Y}$ (terikat), atau sebaliknya semakin kecil variabel $\mathrm{X}$ (bebas), maka semakin kecil pula variabel $\mathrm{Y}$ (terikat).

b. Apabila nilai $\mathrm{r}<0$, maka hubungan antara $\mathrm{X}$ dan $\mathrm{Y}$ merupakan hubungan negatif, yaitu semakin kecil variabel $\mathrm{X}$ (bebas), maka semakin besar nilai variabel $\mathrm{Y}$ (terikat), atau semakin besar variabel $X$ (bebas), maka semakin kecil nilai variabel Y (terikat).

c. Apabila nilai $\mathrm{r}=0$, maka antara variabel $\mathrm{X}$ dan variabel $\mathrm{Y}$ tidak ada hubungan sama sekali. Variabel X tidak ada kontribusi sama sekali terhadap variabel $\mathrm{Y}$.

d. Apabila $\mathrm{r}=1$ berarti terdapat hubungan positif yang sempurna antara variabel $\mathrm{X}$ dengan variabel Y.

e. Apabila nilai $\mathrm{r}=-1$, maka telah terjadi hubungan negatif yang sempurna antara variabel $\mathrm{X}$ (bebas) dengan variabel Y (terikat).

\subsubsection{Analisis Koefisien Determinasi (KD)}

Menurut Supangat (2010:350)

"Koefisien determinasi menunjukkan besaran tingkat kekuatan hubungan antara dua variabel atau lebih dalam bentuk persen (menunjukkan seberapa besar persentase variabel (X) dapat memberikan kontribusi terhadap variabel (Y)". Adapun besarnya kontribusi dari $\mathrm{X}$ terhadap nilai $\mathrm{Y}$ dapat dilakukan dengan rumus sebagai berikut :

$$
K D=r^{2} \times 100 \%
$$

Sumber:Sugiyono(2016:350)

Keterangan :

KD $=$ Koefisien Determinasi

$\mathrm{r}=$ Koefisien Korelasi antara $\mathrm{X}$

dan Y (yang dikuadratkan)

$100 \%=$ Pengalian yang di persentasekan

Untuk mengetahui besaran persentase hubungan antara dua variabel atau lebih dalam bentuk persen dilakukan dengan menggunakan software alat bantu program Statistical Package for Social Science (SPSS) for window versi 23.

\subsubsection{Uji Hipotesis}

1. Uji t

Adapun rumus yang digunakan menurut Sugiyono (2016:184) dalam menguji hipotesis (Uji t) penelitian ini adalah sebagai berikut :

$$
t \text { hitung }=\frac{\mathrm{r} \sqrt{\mathrm{n}-2}}{\sqrt{1}-2}
$$

Sumber:Sugiyono(2016:184)

Keterangan : 
$\mathrm{t}=$ Probabilitas (Jumlah distribusi $\mathrm{t}$ )

$\mathrm{r}=$ Koefisien korelasi

$\mathrm{n}=$ Jumlah sampel/responden

$r=$ Koefisien determinasi

Untuk mengetahui ada atau tidaknya pengaruh antara variabel $\mathrm{X}$ dan variabel $Y$ dilakukan dengan menggunakan software alat bantu program Statistical Package for Social Science (SPSS) for window versi 23. Dengan menggunakan uji searah rumus diatas, agar dapat ditarik kesimpulan dari hipotesis maka hasil perhitungan statistik uji $\mathrm{t}$ ( $\mathrm{t}$ hitung) dibandingkan dengan (t tabel). Degree of Freedom (df) dihitung dengan kriteria sebagai berikut $:$ df $=2$, dimana $\mathrm{n}=$ banyaknya responden yang menjadi sampel dan $2=$ banyaknya variabel yaitu variabel X1 (kualitas Produk) dan X2 (Kualitas pelayanan) dan variabel $\mathrm{Y}$ (keputusan Pembelian) dengan tingkat signifikansi $\alpha=0,05$ atau (5\%).

Kriteria penolakan dan penerimaan hipotesis $\mathrm{H}$ adalah :

1) Jika t hitung > t tabel, maka Ho ditolak dan Ha diterima.

2) Jika t hitung $<\mathrm{t}$ tabel, maka Ho diterima dan Ha ditolak.

Untuk mengetahui hubungan ketiga variabel tersebut, maka di lakukan pengujian hipotesis dengan asumsi sebagai berikut :

a) Kualitas produk

$\mathrm{Ho}_{1}: \mathrm{p}=0$ : Tidak Terdapat pengaruh kualitas produk terhadap keputusan pembelian pada Waroeng Steak Ciputat

Ha1 : $\rho \neq 0$ : Terdapat pengaruh kualitas produk terhadap keputusan pembelian Pada Waroeng Steak Ciputat.

b) Kualitas pelayanan

Ho2: $\rho=0$ : Tidak Terdapat pengaruh kualitas pelayanan terhadap keputusan pembelian Pada Waroeng Steak Ciputat.

Ha2: $\rho \neq 0$ : Terdapat pengaruh kualitas pelayanan terhadap keputusan pembelian Pada Waroeng Steak Ciputat.

\section{Uji F}

Pengujian yang dilakukan ini adalah dengan uji parameter $\beta$ (uji korelasi) dengan menggunakan uji Fstatistik. Untuk menguji pengaruh variabel bebas secara bersama (simultan) terhadap variabel terikat digunakan uji F. Menurut Sugiyono (2015:297-298) dirumuskan sebagai berikut:

$F h=\frac{R^{2} / k}{\left(1-R^{2}\right) / n-k-1}$

Keterangan:

Fh : Nilai uji F

R2 : Koefisien korelasi berganda

$\mathrm{N}$ : Jumlah anggota sampel

$\mathrm{K}$ : Jumlah variabel independen

Distribusi $\mathrm{F}$ ini ditentukan oleh derajat kebebasan pembilang dan penyebut, yaitu $\mathrm{k}$ dan $\mathrm{n}-\mathrm{k}-1$ dengan menggunakan tingkat kesalahan 0,05. Untuk uji F, kriteria yang dipakai adalah:

1. Ho diterima bila $F_{\text {hitung }}<F_{\text {tabel }}$

2. Ho ditolak bila $F_{\text {hitung }}>F_{\text {tabel }}$

Bila Ho diterima, maka dapat diartikan bahwa tidak ada pengaruh dari variabelvariabel independen secara bersamasama atas variabel dependen dan penolakan Ho menunjukkan adanya pengaruh yang signifikan dari variabelvariabel independen yang secara bersama-sama terhadap variabel dependen. Dalam penelitian ini penyelesaiannya menggunakan program Statistical Package for Social Science (SPSS) Versi 23.

\section{ANALISA DAN PEMBAHASAN}

4.1 Karakteristik Responden

1. Berdasarkan Jenis Kelamin

Data responden berdasarkan jenis kelamin, dapat dilihat pada tabel berikut

Tabel 4.1 


\section{Karakteristik Responden Berdasarkan Jenis Kelamin}

$\begin{array}{lll}\text { Jenis } & \text { Frekuensi } & \text { Persentase } \\ \text { Kelamin } & & \\ \text { Laki-laki } & 67 & 67 \% \\ \text { Perempuan } & 33 & 33 \% \\ \text { Jumlah } & \mathbf{1 0 0} & \mathbf{1 0 0 \%}\end{array}$

Sumber : data primer diolah, 2021

Berdasarkan tabel diatas dapat dilihat bahwa persentase jenis kelamin konsumen Waroeng Steak didominasi oleh konsumen berjenis kelamin laki -laki berjumlah 67 orang dengan persentase $67 \%$ sedangkan konsumen berjenis kelamin prempuan berjumlah 33 orang dengan persentase $33 \%$.

\section{Berdasarkan Usia}

Data responden berdasarkan tingkat usia responden, dapat dilihat pada tabel berikut:

$\begin{array}{lll}\text { Usia } & \text { Frekuensi } & \text { Persentase } \\ <18 & 5 & 5 \% \\ 18-30 & 88 & 88 \% \\ 31-40 & 7 & 7 \% \\ 41-50 & 0 & 0 \% \\ >50 & 0 & 0 \% \\ \text { Jumlah } & \mathbf{1 0 0} & \mathbf{1 0 0 \%}\end{array}$

sumber: data primer diolah, 2021

Berdasarkan tabel diatas dapat dilihat bahwa persentase usia konsumen Waroeng Steak di dominasi oleh konnsumen berusia antara 18>30 tahun.

\section{Berdasarkan Pekerjaan}

Data responden berdasarkan penggolongan pekerjaan, dapat dilihat pada tabel berikut:

$\begin{array}{lll}\text { Pekerjaan } & \begin{array}{l}\text { Frekuens } \\ \text { i }\end{array} & \begin{array}{l}\text { Per } \\ \text { e }\end{array} \\ \text { Pelajar/Mahasisw } & 36 & 36 \\ \text { a } & & \\ \text { Buruh } & 3 & 3 \\ \text { Karyawan Swasta } & 43 & 43 \\ \text { PNS } & 2 & 2 \\ \text { Wiraswasta } & 13 & 13 \\ \text { Lainnya } & 3 & 3\end{array}$

sumber: data primer diolah, 2021
Berdasarkan Tabel 4.3 dapat diketahui bahwa sebagian besar responden Waroeng Steak Ciputat adalah pelajar/mahasiswa sebesar 36 orang dengan persentase $36 \%$, buruh sebesar 3 orang dengan persentase $3 \%$, karyawan swasta sebesar 43 orang dengan persentase $43 \%$, Pegawai Negeri Sipil sebesar 2 orang dengan persentase $2 \%$, wiraswasta sebesar 13 orang dengan persentase $13 \%$ dan lainya sebesar 3 orang dengan persentase $3 \%$. Dengan demikian dapat digambarkan bahwa secara umum rata-rata responden adalah pelajar/mahasiswa dan karyawan swasta.

4.2 Analisa Deskriptif Penilaian atau Jawaban Responden

4.2.1 Tanggapan Responden Terhadap Kualitas Produk

Pada bagian ini akan disajikan gambaran responden mengenai kualitas produk yang di hasilkan oleh Waroeng Steak Ciputat dalam menarik konsumen. Gambaran responden ini dibuat dengan melihat seberapa besar tanggapan konsumen Waroeng Steak Ciputat :

\section{Tabel 4.4}

Tanggapan Variabel Kualitas Produk Pada Waroeng Steak Ciputat

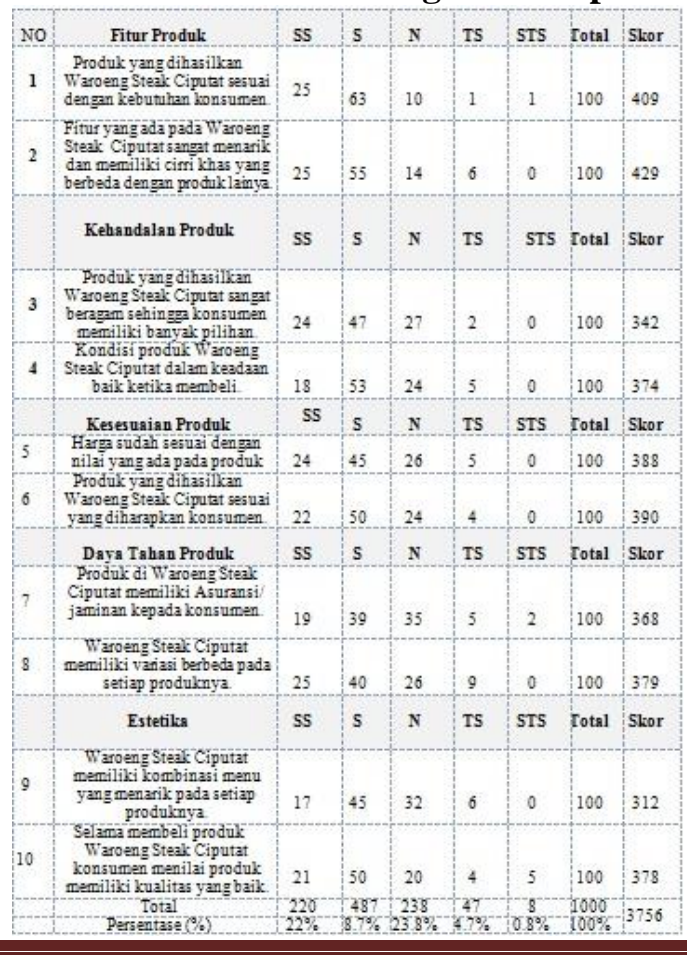


sumber: data primer diolah, 2021

Berdasarkan tabel 4.4 di atas, pernyataan pada variabel kualitas produk, yang menjawab sangat setuju, setuju, kurang setuju, tidak setuju dan sangat tidak setuju sebesar $100 \%$.

\subsubsection{Tanggapan Responden Terhadap} Kualitas Pelayanan

Tanggapan responden mengenai kualitas pelayanan yang di hasilkan oleh Waroeng Steak Ciputat dalam menarik konsumen dapat dilihat pada tabel berikut:

\section{Tabel 4.5}

Tanggapan Variabel Kualitas Pelayanan pada Waroeng Sateak Ciputat

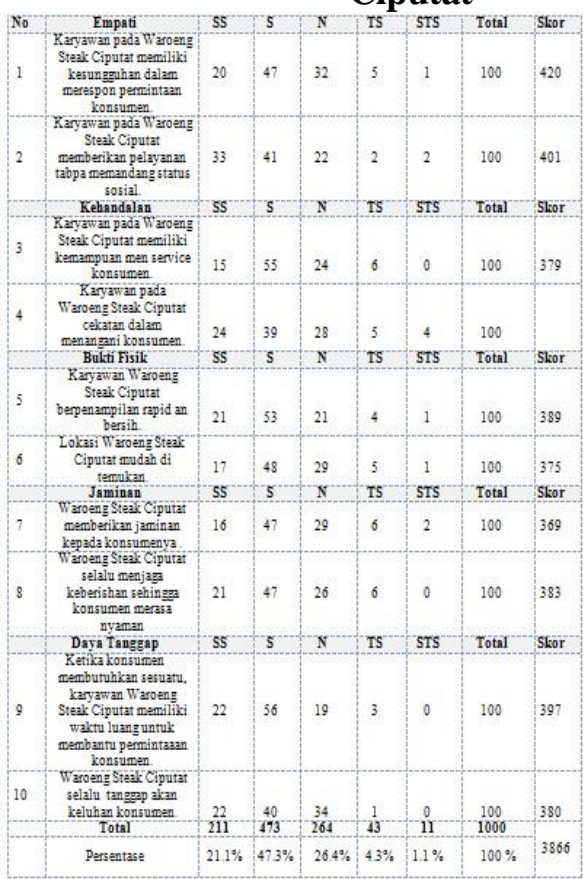

sumber : data primer diolah, 2021

Berdasarkan tabel 4.5 di atas, penelitian respomden atas pernyataan pada variabel Kualitas Pelayanan , yang menjawab sangat setuju ,setuju ,kurang setuju, tidak setuju dan sangat tidak setuju sebesar $21.1 \%+47.3 \%+26.4 \%+4.3 \%+$ $1.1 \%=100 \%$.

\subsubsection{Tanggapan Responden Terhadap Keputusan Pembelian}

Tanggapan responden mengenai proses keputusan pembelian Waroeng Steak Ciputat yang ditunjukan berikut ini:

\section{Tabel 4.6}

Tanggapan Variabel Keputusan Pembelian Pada Waroeng Steak Ciputat

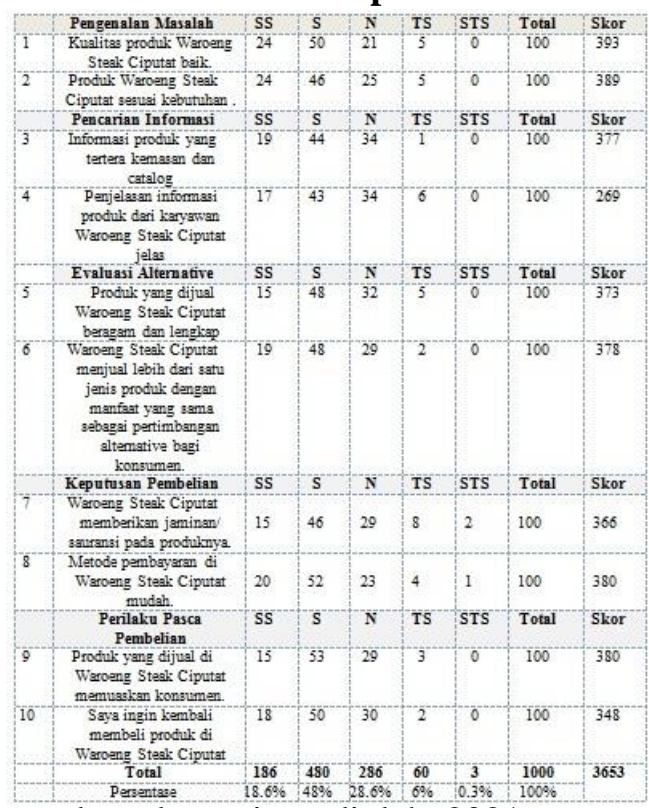
sumber: data primer diolah, 2021

Berdasarkan tabel 4.6 di atas mengenai pernyataan pada variabel kualitas produk, yang menjawab sangat setuju, setuju, kurang setuju, tidak setuju dan sangat tidak setuju sebesar $100 \%$.

\subsection{Pengujian Instrumen Data Penelitian}

1. Uji Validitas

\section{a. Pengujian Validitas Untuk Variabel Kualitas Produk (X1)}

Tabel 4.7

\section{Hasil Uji Validitas Variabel Kualitas} Produk (X1)

\begin{tabular}{|c|l|l|l|c|}
\hline No & Pernyatan & $\mathrm{r}$ hitung & $\mathrm{r}$ tabel & Keputusan \\
\hline 1 & Pernyatan 1 & 0,409 & 0.165 & Valid \\
\hline 2 & Pernyatan 2 & 0.453 & 0.165 & Valid \\
\hline 3 & Pernyatan 3 & 0.552 & 0.165 & Valid \\
\hline 4 & Pernyatan 4 & 0.540 & 0.165 & Valid \\
\hline 5 & Pernyatan 5 & 0.613 & 0.165 & Valid \\
\hline 6 & Pernyatan 6 & 0.681 & 0.165 & Valid \\
\hline 7 & Peranyatan 7 & 0.699 & 0.165 & Valid \\
\hline 8 & Pernyatan 8 & 0.669 & 0.165 & Valid \\
\hline 9 & Pernyatan 9 & 0.682 & 0.165 & Valid \\
\hline 10 & Pernyatan 10 & 0.600 & 0.165 & Valid \\
\hline
\end{tabular}

sumber: data primer diolah, 2021 
Berdasarkan tabel di atas, dapat dilihat bahwa dari 10 pertanyaan untuk variabel kualitas produk (X1) semua pertanyaan dinyatakan valid dimana semua item pernyataan memiliki nilai corrected item total correlation lebih besar dari 0,165 atau $\mathrm{r}$ hitung $>\mathrm{r}$ tabel

\section{b. Pengujian Validitas Untuk Variabel Kualitas Pelayanan (X2) \\ Tabel 4.8}

\section{Hasil Uji Validitas Variabel Kualitas}

\section{Pelayanan (X2)}

\begin{tabular}{|c|l|l|l|l|}
\hline No & Pernyatan & r hitung & r tabel & Keputusan \\
\hline 1 & Pernyataan 1 & 0.538 & 0.165 & Valid \\
\hline 3 & Pernyatasn 2 & 0.571 & 0.165 & Valid \\
\hline 4 & Pernyataan 3 & 0.649 & 0.165 & Valid \\
\hline 5 & Pernyataan 4 & 0.664 & 0.165 & Valid \\
\hline 6 & Pernyataan 6 & 0.454 & 0.165 & Valid \\
\hline 7 & Pernyataan 7 & 0.611 & 0.165 & Valid \\
\hline 9 & Pernyataan 8 & 0.460 & 0.165 & Valid \\
\hline 10 & Pernyataan 9 & 0.469 & 0.165 & Palid \\
\hline
\end{tabular}

sumber: data primer diolah, 2021

Berdasarkan tabel di atas, dapat dilihat bahwa dari 10 pernyataan untuk variabel Kualitas Pelayanan (X2) dinyatakan valid dimana semua item pernyataan memiliki nilai corrected item total correlation lebih besar dari 0,165 atau $r$ hitung $>r$ tabel. Untuk itu kuesioner yang digunakan layak untuk diolah sebagai penelitian.

\section{c. Pengujian Validitas Untuk Variabel Keputusan Pembelian}

Tabel 4.9

\section{Hasil Uji Validitas Variabel Keputusan} Pembelian (Y)

\begin{tabular}{|c|l|l|l|l|}
\hline No & Pernyatas & \multicolumn{1}{|c|}{$\mathrm{r}$ hitung } & $\mathrm{r}$ tabel & Keputusan \\
\hline 1 & Pernyataan 1 & 0.473 & 0.165 & Valid \\
\hline 2 & Pernyataan 2 & 0.616 & 0.165 & Valid \\
\hline 3 & Pernyatas 3 & 0.585 & 0.165 & Valid \\
\hline 4 & Pernyataan 4 & 0.657 & 0.165 & Valid \\
\hline 5 & Pernyataan 5 & 0.707 & 0.165 & Valid \\
\hline 6 & Pernyataan 6 & 0.705 & 0.165 & Valid \\
\hline 7 & Pernyataan 7 & 0.566 & 0.165 & Valid \\
\hline 8 & Pernyataan 8 & 0.642 & 0.165 & Valid \\
\hline 9 & Pernyataan 9 & 0.588 & 0.165 & Valid \\
\hline 10 & Pernyataan 10 & 0.526 & 0.165 & Valid \\
\hline & & & \\
\hline
\end{tabular}

sumber: data primer diolah, 2021
Berdasarkan tabel di atas, dapat dilihat bahwa dari 10 pernyataan untuk variabel Keputusan Pembelian (X2) dinyatakan valid, hal ini dibuktikan dengan semua item pernyataan memiliki nilai $r$ hitung > $\mathrm{r}$ tabel (0.165).

\section{Uji Reliabilitas}

Uji reliabilitas dimaksudkan untuk menguji kehandalan atau kestabilan jawaban dari responden. kreteria dalam pengambilan keputusan reliabilitas dan tidaknya pernyataan adalah sebagai berikut:

a. Jika nilai rea > 0.60 maka butir pernyataan dikatakan reliabel.

b. Jika nilai rea < 0.60 maka butir pernyataan dikatakan tidak reliabel.

Taraf signifikan a $=0.05(5 \%)$ dengan tingkat kepercayaan pemgujianya adalah 95\%. Hasil perhitungan uji reliabilitas pada masing-masing variabel, dapat dilihat pada tabel berikut:

Tabel 4.10

\section{Hasil Uji Reliabilitas Data}

\begin{tabular}{|c|l|l|l|l|}
\hline No & \multicolumn{1}{|c|}{ Variabel } & Nilai rea & ketentuan & Kesimpulan \\
\hline 1 & Kualitas produk & 0.796 & 0.60 & Reliabel \\
\hline 2 & Kualitas Pelayanan & 0.770 & 0.60 & Reliabel \\
\hline 3 & Keputusan Pembelian & 0.808 & 0.60 & Reliabel \\
\hline
\end{tabular}

sumber: data primer diolah, 2021

Berdasarkan hasil uji reliabelitas pada tabel diatas, dapat disimpulkan reliabel, hal itu dibuktikan dengan nilai rea $>0.60$ dengan demikian layak untuk di teruskan.

\subsection{Hasil Uji Asumsi Klasik}

\subsubsection{Uji Normalitas}

Uji normalitas dimaksudkan untuk menguji apakah dalam model regresi variabel dependen dan variabel independen memiliki distribusi normal atau tidak. Dalam pengujian dilalukan dengan mengamati histogram atau nilai residual dan grafik normal probability plot. Deteksi pengambilan keputusan adalah dengan syarat titik- titik menyebar di sekitar garis dan mengikuti arah garis diagonal. Adapun hasil uji normalitas adalah sebagai berikut : 


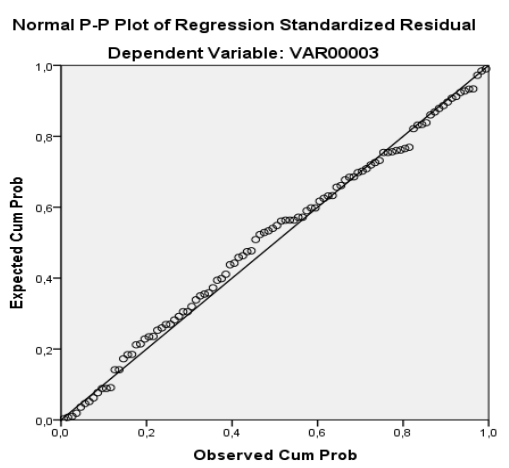

sumber: data primer diolah, 2021

Gambar 4.1

P-p plot Uji normalitas - Diagram Penyebaran titik Residual

Pada gambar grafik diatas dapat dilihat bahwa grafik normal probability plot menunjukan pola grafik yang normal yang mengidentifikasikan bahwa model regresi memenuhi asumsi normal hal ini terlihat dari titik-titik yang menyebar disekitar grafik normal mengikuti garis diagonal.

\subsubsection{Uji Multikolinearitas}

Uji Multikolonearitas dimaksudkan untuk menguji apakah model regresi ditemukan adanya korelasi antar variabel independen. Untuk mendeteksi adanya multikolonearitas, dapat dilihat dari tolerance value atau infation Factor (VIF) dengan ketentuan sebagai berikut :

1) Jika nilai VIF > 10 dan nilai tolerance $>1$ maka terjadi muktikolonearitas

2) Jika nilai VIF $<10$ dan nilai tolerance $<1$ maka tidak terjadi muktikolonearitas

Hasil multikolonearitas dapat dilihat pada tabel berikut :

Tabel 4.11

Hasil Multikolonearitas Coefficients $^{\mathrm{a}}$

\begin{tabular}{|c|c|c|c|c|c|c|c|c|}
\hline \multirow[b]{2}{*}{ Model } & & \multicolumn{2}{|c|}{ Unstandardized Coefficients } & \multirow{2}{*}{$\begin{array}{c}\text { Standardized } \\
\text { Coefficients }\end{array}$} & \multirow[b]{2}{*}{ t } & \multirow[b]{2}{*}{ Sig. } & \multicolumn{2}{|c|}{ Collinearity Statistics } \\
\hline & & $B$ & Std. Error & & & & Tolerance & $\mathrm{VIF}$ \\
\hline \multirow[t]{3}{*}{1} & (Constant) & 14,372 & 3,734 & & 3,849 &, 000 & & \\
\hline & KualiliasProduk & 349 & 103 & 351 & 3,386 & , 001 & 672 & 1,488 \\
\hline & KualitasPelayanan & .267 & 104 & .265 & 2,556 & .012 & .672 & 1,488 \\
\hline
\end{tabular}

sumber: data primer diolah, 2021

Dari tabel 4.11 dapat di simpulkan bahwa model regresi layak di pakai dalam penelitian ini karena syarat untuk untuk tidak terjadi multikolonearitas sudah terpenuhi yakni nilai tolerance $>0,10$ atau sama dengan nilai VIF $<10$ yakni nilai tolerance kualitas produk dan kualitas pelayanan sebesar $1,488>0,10$ dan VIF $1.488<0.10$.

\subsubsection{Uji Heteroskedasitas}

Uji Heteroskedasitas di maksudkan apakah model dalam regresii terjadi keditaksamaan varian residual dari satu pengamatan ke pengamatan lain. Salah satu dari mendekteksi terjadi heteroskedastisitas atau tidak adalah dengan melihat grafik scastter plot pada nilai prediksi variabel terikat (ZPREED) dan nilai residualnya (SRESID). Kreteira pengambilan keputusan adalah jika titik- titik pada gambar yang dihasilkan membentuk pola tertentu yang teratur maka telah terjadi heteroskedasitas. Namun jika menyebar tanpa membentuk pola tertentu, maka model tersebut tidak terjadi heteroskedasitas. Adapun hasil uji heteroskedasitas dapat di lihat pada gambar berikut ini :

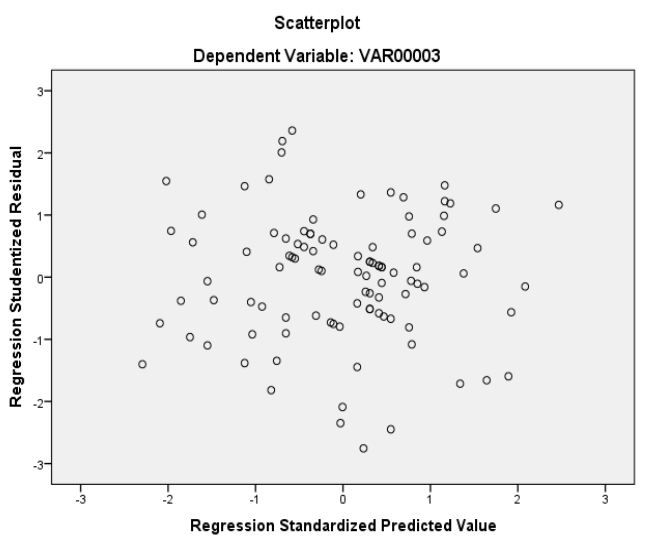

sumber: data primer diolah, 2021

Gambar 4.2 Hasil Uji

Heteroskedasitas

Pada gambar diatas, titik-titik pada grafik scatter plot tidak mempunyai pola penyebaran yang jelas dan titik-titik tersebut menyebar diatas dan di bawah angka 0 pada sumbu Y dengan demikian hal ini menunjukan bahwa tidak menunjukan 
bahwa tidak terdapat gangguan heteroskedasitas.

\subsubsection{Hasil Uji Regresi Linear Berganda}

Uji regresi linier berganda dimaksudkan untuk mengetahui seberapa besar pengaruh variabel Kualitas Produk (X1) dan Kualitas Pelayanan (X2) terhadap Keputusan Pembelian (Y). Adapun hasil analisis regresi linear berganda sebagai berikut :

Tabel 4.12

Hasil Uji Regresi Berganda Variabel Kualitas Produk (X1) dan Kualitas Pelayanan (X2) Terhadap Keputusan Pembelian (Y)

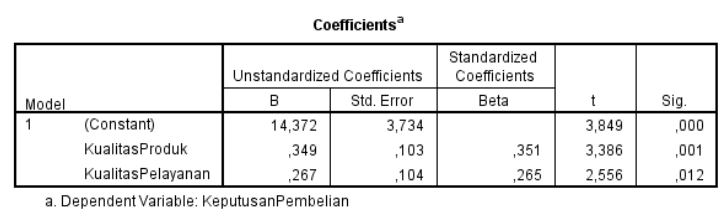

sumber: data primer diolah, 2021

Berdasarkan hasil analisi regresi pada tabel di atas, di peroleh persamaan regresi $Y=14,372+0.349 X 1+0.267 X 2$, dari persamaan regresi tersebut dapat disimpulkan:

a. Nilai konstanta sebesar 14,372 yang berarti jika variabel kualitas produk X1) dan kualitas pelayanan (X2) bernilai nol, maka keputusan pembelian bernilai 14,372 .

b. Nilai beta $(\beta 1)$ sebesar 0,349 yang berarti setiap perubahan satu satuan pada variabel kualitas produk (X1) akan mengakibatkan perubahan pada Y sebesar 0,349.

c. Nilai beta $(\beta 2)$ sebesar 0,267 yang berarti setiap perubahan 1 satuan pada variabel kualitas pelayanan (X2) akan mengakibatkan perubahan pada $Y$ sebesar 0,267 .

\subsubsection{Hasil Uji Korelasi Product} Moment

Analisis korelasi dimaksudkan untuk mengetahui tingkat hubungan atau pengaruh antara variabel independen terhadap variabel dependen baik secara parsial maupun secara simultan. Adapun hasil analisisnya sebagai berikut:
Tabel 4.13

Hasil Uji Koefesien Korelasi (Secara Parsial ) Variabel Kualitas Produk (X1) Terhadap Keputusan Pembelian (Y)

Model Summary ${ }^{\mathrm{b}}$

\begin{tabular}{|l|l|r|r|r|}
\hline Model & R & R Square & $\begin{array}{c}\text { Adjusted R } \\
\text { Square }\end{array}$ & $\begin{array}{c}\text { Std. Error of } \\
\text { the Estimate }\end{array}$ \\
\hline 1 &, $503^{\text {a }}$ &, 253 &, 245 & 4,07121 \\
\hline
\end{tabular}

a. Predictors: (Constant), KualitasProduk

b. Dependent Variable: KeputusanPembelian

sumber: data primer diolah, 2021

Berdasarkan tabel 4.13 di atas, di peroleh nilai koefesien korelasi (R) sebesar 0,503 maka dapat disimpulkan bahwa variabel Kualitas Produk (X1) memiliki tingkat kekuatan yang sedang terhadap keputusan pembelian (Y).

Tabel 4.14

Hasil Uji Koefesien Korelasi (Secara Parsial ) Variabel Kualitas Pelayanan (X2) Terhadap Keputusan Pembelian (Y)

\begin{tabular}{|l|l|r|r|r|}
\hline Model & R & R Square & $\begin{array}{c}\text { Adjusted R } \\
\text { Square }\end{array}$ & $\begin{array}{c}\text { Std. Error of } \\
\text { the Estimate }\end{array}$ \\
\hline 1 &, $466^{\text {a }}$ &, 217 &, 209 & 4,16704 \\
\hline
\end{tabular}
a. Predictors: (Constant), KualitasPelayanan
b. Dependent Variable: KeputusanPembelian

sumber: data primer diolah, 2021

Berdasarkan tabel 4.14 di atas, diperoleh nilai koefesien korelasi (R) sebesar 0,466 dan sesuai dengan hasil di atas maka dapat disimpulkan bahwa variabel Kualitas Pelayanan (X2) memiliki tingkat kekuatan yang sedang terhadap Keputusan Pembelian (Y).

Tabel 4.15

Hasil Uji Koefesien Korelasi (Secara Simultan) Variabel Kualitas Produk (X1) dan Kualitas Pelayanan (X2) Terhadap Keputusan Pembelian (Y) Model Summary ${ }^{\mathrm{b}}$

\begin{tabular}{|c|c|c|c|c|}
\hline Model & $\mathrm{R}$ & R Square & $\begin{array}{c}\text { Adjusted R } \\
\text { Square }\end{array}$ & $\begin{array}{l}\text { Std. Error of } \\
\text { the Estimate }\end{array}$ \\
\hline 1 & $548^{a}$ &, 300 &, 285 & 3,96089 \\
\hline
\end{tabular}


sumber: data primer diolah, 2021

Berdasarkan tabel di atas, diperoleh nilai koefesien korelasi (R) sebesar 0,548 dan sesuai dengan tabel maka dapat disimpulkan bahwa variabel Kualitas Produk (X1) dan Kualitas Pelayanan (X2) secara simultan memiliki tingkat kekuatan hubungan yang sedang terhadap Keputusan Pembelian (Y).

\subsubsection{Hasil Uji Koefisien Determinasi}

Analisi koefesien determinasi dimaksudkan untuk mengetahui persentase pengaruh variabel independen terhadap variabel dependen baik secara parsial maupun secara simultan, adapun hasil analisinya sebagai berikut :

\section{Tabel 4.16}

Hasil Data Koefesien Determinasi (Secara Parsial) Variabel Kualitas Produk (X1) Terhadap Keputusan Pembelian (Y)

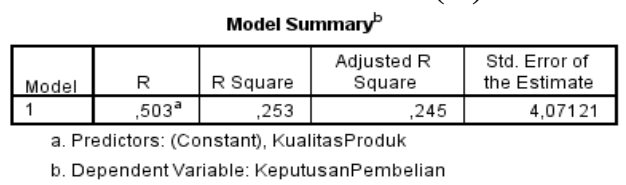

sumber: data primer diolah, 2021

Berdasarkan tabel diatas, dapat diperoleh nilai determinasi ( $\mathrm{R}$ square) sebesar 0.253 memiliki kontribusi sedang terhadap variabel Keputusan Pembelian (Y) sebesar $25.3 \%$ sisanya $74.7 \%$ dipengaruhi faktor lain.

Tabel 4.17

Hasil Data Koefesien Determinasi (Secara Parsial) Variabel Kualitas Pelayanan (X2) Terhadap Keputusan Pembelian (Y)

\begin{tabular}{|l|c|r|r|r|}
\hline Model Summary \\
\hline Model & $R$ & R Square & $\begin{array}{c}\text { Adjusted R } \\
\text { Square }\end{array}$ & $\begin{array}{c}\text { Std. Error of } \\
\text { the Estimate }\end{array}$ \\
\hline 1 &, $466^{\text {a }}$ &, 217 &, 209 & 4,16704 \\
\hline
\end{tabular}
a. Predictors: (Constant), KualitasPelayanan
b. Dependent Variable: KeputusanPembelian

sumber: data primer diolah, 2021

Berdasarkan tabel diatas, dapat diperoleh nilai determinasi ( $\mathrm{R}$ square) sebesar 0.217 memiliki kontribusi kecil terhadap variabel Keputusann pembelian (Y) sebesar $21,7 \%$ sisanya $78,3 \%$ dipengaruhi faktor lain.

$$
\text { Pengujian data selanjutnya }
$$
menggunakan analisis koefesien determinasi secara simultan, analisis simultan dimaksudkan untuk mengetahui persentase kontribusi pengaruh variabel independen secara bersama-sama terhadap variabel dependen. Adapun hasil analisisnya sebagai berikut:

Tabel 4.18

Hasil Data Koefesien Determinasi (Secara Parsial) Variabel Kualitas Produk (X1) dan Kualitas Pelayanan (X2) Terhadap Keputusan Pembelian (Y)

Model Summary ${ }^{b}$

\begin{tabular}{|l|l|r|r|r|}
\hline Model & \multicolumn{1}{|c|}{ R } & R Square & $\begin{array}{c}\text { Adjusted R } \\
\text { Square }\end{array}$ & $\begin{array}{c}\text { Std. Error of } \\
\text { the Estimate }\end{array}$ \\
\hline 1 &, $548^{\mathrm{a}}$ &, 300 &, 285 & 3,96089 \\
\hline
\end{tabular}
a. Predictors: (Constant), KualitasProduk,
KualitasPelayanan
b. Dependent Variable: KeputusanPembelian

sumber: data primer diolah, 2021

Berdasarkan perhitungaan pada tabel di atas, diperoleh nilai koefesien determinasi (R-square) sebesar 0,300, maka dapat di simpulkan bahwa variabel Kualitas Produk (X1) dan Kualitas Pelayanan (X2) secara bersama-sama memiliki kontribusi terhadap Keputusan Pembelian (Y) sebesar 30\% sedangkan sisanya sebesar $70 \%$ dipengaruhi faktor lainya.

\subsection{Hasil Uji Hipotesis}

\subsubsection{Pengujian Hipotesis Secara Parsial (uji t) \\ Pengujian hipotesis secara parsial} dimaksudkan untuk menguji secara stastistik (uji t) apakah rumusan hipotesis yang dibuat diterima atau tidak. Pengajuan dalam penelitian ini antara variabel independen terhadap variabel dependen secara parsial, signifikan dalam penelitian ini digunakan $10 \% \quad(0,1)$ dengan 
membandingkan $\mathrm{t}$ hitung dengan $\mathrm{t}$ tabel dengan kreteria sebagai berikut :

1) Jika t hitung $>\mathrm{t}$ tabel, maka Ho dan H1 diterima.

2) Jika t hitung $>\mathrm{t}$ tabel, maka Ho dan H1 ditolak.

Besarnya nilai $t$ tabel dicari dengan menggunakan rumus berikut:

t tabel : ta.df(Taraf Alpha x Degree of freedom

$\alpha \quad$ : tingkat kesalahan $10 \%$

df $:(n-3)$, maka diperoleh $(100-3)=97$

$\mathrm{t}$ tabel : 1,660

\section{Kualitas Produk (X1) terhadap Keputusan Pembelian (Y) \\ Tabel 4.19}

Hasil Uji t Variabel Kualitas Produk (X1) Terhadap Keputusan Pembelian (Y)

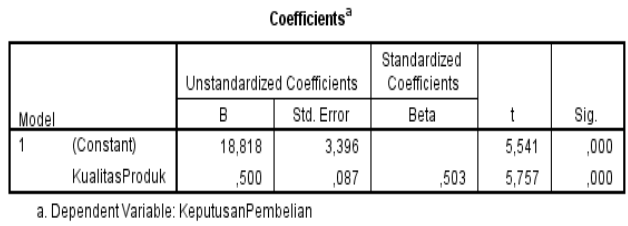

sumber: data primer diolah, 2021

Berdasarkan hasil analisis pada tabel diatas diperoleh nilai $t$ hitung $>\mathrm{t}$ tabel atau $(5,757>1.660)$ hal ini di perkuat dengan nilai signifikan $0,000<0,05$, untuk itu hipotesis pertama yang menyatakan terdapat pengaruh yang positif dan signifikan secara parsial antara kualitas produk terhadap keputusan pembelian dapat di terima.

\section{Kualitas Pelayanan (X2) terhadap Keputusan Pembelian (Y) \\ Tabel 4.20}

Hasil Uji t Variabel Kualitas Pelayanan (X2) terhadap keputusan pembelian (Y)

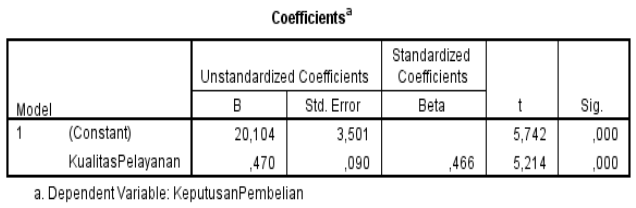

sumber: data primer diolah, 2021
Berdasarkan hasil analisis pada tabel diatas diperoleh nilai $t$ hitung $>t$ tabel atau $(5,214>1.660)$ hal ini di perkuat dengan nilai signifikan $0,000<0,05$, untuk itu hipotesis kedua yang menyatakan terdapat pengaruh yang positif dan signifikan secara parsial antara kualitas pelayanan terhadap keputusan pembelian dapat diterima.

\subsubsection{Pengujian Hipotesis Secara Simultan (uji F) \\ Pengujian hiotesis secara simultan} dimaksudkan untuk mengetahui pengaruh variabel kualitas produk (X1) dan kualitas pelayanan (X2) secara simultan terhadap keputusan pembelian (Y) yang di lakukan dengan uji stastistik $F$ (uji simultan) signifikansi penelitian ini digunakan $10 \%$ $(0,1)$ dengan membandingkan $\mathrm{F}$ tabel dengan kreteria sebagai berikut :

a) Jika $\mathrm{F}$ hitung < $\mathrm{F}$ tabel, maka $\mathrm{H} 3$ diterima dan $\mathrm{H} 1, \mathrm{H} 2$ ditolak

b) Jika $\mathrm{F}$ hitung < $\mathrm{F}$ tabel, maka $\mathrm{H} 3$ ditolak dan $\mathrm{H} 1, \mathrm{H} 2$ diterima

c) Besarnya $F$ tabel di cari dengan ketentuan : (n-k-1) maka di peroleh $(100-2-1)=97$ sehingga $\mathrm{F}$ tabel $=3,09$ Adapun hasil pengujian hipotesis tersebut diatas adalah sebagai berikut:

Tabel 4.21

Hasil Pengolahan Data Pengujian F Simultan

\begin{tabular}{|c|c|c|c|c|c|c|}
\hline \multicolumn{7}{|c|}{ ANOVA $^{a}$} \\
\hline Model & & $\begin{array}{l}\text { Sum of } \\
\text { Squares }\end{array}$ & df & Mean Square & $\mathrm{F}$ & Sig. \\
\hline \multirow[t]{3}{*}{1} & Regression & 651,914 & 2 & 325,957 & 20,777 & $.000^{\mathrm{b}}$ \\
\hline & Residual & 1521,796 & 97 & 15,689 & & \\
\hline & Total & 2173,710 & 99 & & & \\
\hline
\end{tabular}

b. Predictors: (Constant), KualitasProduk, KualitasPelayanan

sumber: data primer diolah, 2021

Berdasarkan pengujian pada tabel diatas diperoleh $\mathrm{F}$ hitung > tabel atau $(20,777>3,09)$ hal ini juga di perkuat dengan nilai probability signifikan secara bersama sama antara variabel kulitas produk dan kualitas pelayanan terhadap keputusan pembelian dapat di terima. 


\subsection{Pembahasan Hasil Penelitian \\ 4.6.1. Pengaruh Kualitas Produk (X1) Terhadap Keputusan Pembelian (Y) \\ Berdasarkan hasil perhitungan dapat} diketahui variabel kualitas produk (X1) memiliki tingkat hubungan sebesar 0,503 atau sedang terhadap keputusan pembelian (Y) dengan kontribusi pengaruh sebesar 0,253 atau $25,3 \%$, pengujian hipotesis diperoleh $\mathrm{t}$ hitung > tabel atau (5,757> 1,660) dengan nilai signifikan $0,000<0,05$ untuk itu hipotesis pertama yang menyatakan terdapat pengaruh yang positif dan signifikan secara parsial antara kualitas produk terdapat keputusan pembelian dapat di terima.

\subsubsection{Pengaruh Pelayanan (X2) Terhadap Keputusan Pembelian (Y)}

Berdasarkan hasil perhitungan dapat diketahui variabel kualitas pelayanan (X2) memiliki tingkat hubungan sebesar 0,466 atau sedang terhadap keputusan pembelian (Y) dengan kontibusi pengaruh sebesar 0,217 atau $251,7 \%$, pengujian hipotesis diperoleh t hitung > tabel atau $(5,217>$ $1,660)$ dengan nilai signifikan $0,000<0,05$ , untuk itu hipotesis pertama yang menyatakan terdapat pengaruh yang positif dan signifikan secara parsial antara kualitas produk terhadap keputusan pembelian dapat di terima.

\subsubsection{Pengaruh Kualitas Produk (X1) dan Kualitas Pelayanan (X2) Secara Simultan Terhadap Keputusan Pembelian (Y)}

Berdasarkan hasil perhitungan dapat diketahui variabel kualitas produk (X1) dan kualitas pelayanan (X2) berpengaruh terhadap keputusan pembelian dengan persamaan regresi $\mathrm{Y}=14,372+0.349 \mathrm{X} 1$ $+0.267 \mathrm{X} 2$, hasil analisis regresi tingkat hubungan antara variabel kualitas produk dan kualitas pelayanan terhadap keputusan pembelian sebesar 0.300 atau $30 \%$ sedangkan sisanya $70 \%$ di pengaruhi faktor lain. Pengujian hipotesis menggunakan stastistik di peroleh nilai $\mathrm{F}$ hitung $>\mathrm{F}$ tabel atau $(20,77>3,09)$ dengan nilai probability signifikan $0,000<0,05$ untuk itu hipotesis ketiga yang menyatakan terdapat pengaruh yang positif dan signifikan secara simultan antara kualitas produk dan kualitas pelayanan terhadap keputusan pembelian dapat diterima.

\section{PENUTUP}

\subsection{Kesimpulan}

1. Berdasarkan hasil pengujian diperoleh nilai $t$ hitung $>t$ tabel atau $(5,757>1.660)$ hal ini di perkuat dengan nilai signifikan $0,000<0,05$, untuk itu hipotesis pertama yang menyatakan terdapat pengaruh positif dan signifikan secara parsial antara kualitas produk terhadap keputusan pembelian diterima.

2. Berdasarkan hasil pengujian diperoleh nilai $t$ hitung $>t$ tabel atau $(5,214>1.660)$ hal ini di perkuat dengan nilai signifikan $0,000<0,05$, untuk itu hipotesis kedua yang menyatakan terdapat pengaruh positif dan signifikan secara parsial antara kualitas produk terhadap keputusan pembelian diterima.

3. Berdasarkan hasil pengujian diperoleh $\mathrm{F}$ hitung $>\mathrm{F}$ tabel atau ( $20,777>3,09$ ) hal ini juga di perkuat dengan nilai probability signifikan secara bersama-sama $0,000<0,05$ antara variabel kulitas produk dan kualitas pelayanan terhadap keputusan pembelian dapat di terima.

\subsection{Saran}

1. Hasil penelitian pada tanggapan variabel kualitas produk diperoleh skor tertinggi (S) setuju 487 atau $48,7 \%$, namun berdasarkan hasil penelitian masih banyak konsumen yang mengeluhkan mengenai kualitas produk yang tidak sesuai harapan. Pihak manajemen sebaiknya dapat memperhatikan hal 
tersebut agar konsumen dapat nyaman memilih produk dan berdampak pada keputusan pembelian dan meningkatkan kualitas produk agar konsumen loyal terhadap Waroeng Steak Ciputat.

2. Hasil penelitian pada tanggapan variabel kualitas pelayanan di peroleh skor tertinggi (S) setuju 473 atau 47,3\%, namun berdasarkan hasil penelitian masih banyak konsumen yang mengeluhkan mengenai kualitas pelayanan yang tidak sesuai harapan. Konsumen mengeluhkan pelayanan terhadap pelayanan waroeng steak yang kurang tanggap terhadap konsumen. Pihak manajemen sebaiknya memperhatikan hal tersebut agar konsumen dapat nyaman dalam kualitas pelayanan yang diberikan dan berdampak pada keputusan pembelian dan meningkatkan kualitas pelayanan agar konsumen loyal terhadap Waroeng Steak Ciputat.

3. Hasil penelitian pada tanggapan variabel keputusan pembelian diperoleh skor tertinggi (S) setuju 480 atau $48 \%$, dari hasil penelitian masih banyak konsumen yang belum loyal dengan produk Waroeng Steak Ciputat. Hendaknya manajemen Warung Steak Ciputat menambah menu baru yang menarik sehingga menumbuhkan daya minat konsumen, serta memberikan referensi produk kepada konsumen sehingga konsumen tertarik dalam melakukan keputusan pembelian.

\section{DAFTAR PUSTAKA}

Allysa N., Maharani N., \& Estri S. 2018. Pengaruh Kualitas Produk Terhadap Keputusan Pembelian Pada Ozon Parfume Fragnance. Prosiding Manajemen (Agustus 2018) Vol.4 No.2.

Amrullah, Siburian S., P., \& Zainurossalami. 2016. Pengaruh Kualitas Produk dan Kualitas Layanan Terhadap Keputusan Pembelian Sepeda Motor Honda. Kinerja : Jurnal Ekonomi dan Manajemen, Volume 13, (2), 2016.Andri. Feriyanto dan Endang Shynta Triana. 2015. Managemen (3 in 1). Cetakan pertama. Mediatera : Yogyakarta.

Anwar Iful. 2015. Pengaruh Harga Dan Kualitas Produk Terhadap Keputusan Pembelian Bunchbead Kota Malang. Jurnal Ilmu Dan Riset Manajemen. Vol.4.No.12 (2015).ISSN:2461-0593.

Assauari, Sofyan. 2015. Managemen Pemasaran. Cetakan ke-14. PT Raja Grafindo Persada: Jakarta.

Astuti R. \& Abdullah I. 2017. Pengaruh Kualitas Produk dan Promosi Terhadap Keputusan Pembelian Pakaian di Usaha Mikro Kecil Menengah. Jurnal Ilman Vol 5 No.2,14-23.

Haryoko, U. B., Pasaribu, V. L. D., \& Ardiyansyah, A. (2020). PENGARUH HARGA DAN KUALITAS PELAYANAN TERHADAP KEPUASAN KONSUMEN PADA FIRMAN DEKORASI (WEDDING ORGANIZER). POINT: Jurnal Ekonomi Dan Manajemen, 2(1). 
Daryono. 2013. Sari Kuliah Manajemen Pemasaran. Cetakan II Januari. PT.Sarana Tutorial Nurani Sejahtera:Bandung.

Keller dan Amstrong. 2014. Prinsip Prinsip Pemasaran. Edisi Ke-12, jilid - 1 Erlangga: Jakarta.

Kotler dan Keller. 2012. Manejemen Pemasaran. Edisi Ke-12 Jilid ke-1. Erlangga : Jakarta.

Kotler Philip, dan Gary Amstrong. 2012. Principles Of Marketing. Global Edition, 14 Edition, Pearson Education

Kotler, Philip dan Kevin Lane Keller. 2015. Managemen Pemasaran. Edisi 13 jilid 2 Erlangga: Jakarta

Kotler, Philip, Kevin Lane Keller. 2012. Marketing Management, 14th Edition United States of America : Pearson

Nopriani. 2016. Pengaruh Atribut Produk Terhadap Keputusan Pembelian Kecap Manis ABC (Studi UD, Toko Harapan Besar Didesa Suka Maju DK 4D), Univeritas Pasir Pengairan. Jurnal Mahasiswa Prodi Manajemen Fakultas Ekonomi dan Bisnis. Vol. 3 No.2 (2016)

Pasaribu, V. L. D. (2020). ANALISIS PENGARUH PROMOSI, KUALITAS PRODUK DAN DESAIN KEMASAN TERHADAP KEPUTUSAN PEMBELIAN HAND AND BODY LOTION MEREK CITRA (Studi Kasus Carrefour Pamulang, Tangerang Selatan). Jurnal Pemasaran Kompetitif, 1(4).

Pasaribu, V. L. D., \& Prayoga, M. Y. S. (2019). Pengaruh Kualitas Produk Baju Batik Hem Terhadap Kepuasan Pelanggan Pada Home Industri Batik Sahara Indah. Jurnal Pemasaran Kompetitif, 2(2), 77-83.
Pasaribu, V. L. D. PENGARUH STORE ATMOSPHERE TERHADAP KEPUTUSAN PEMBELIAN PADA RESTORAN DE'COST GIANT PAMULANG SQUARE TANGERANG SELATAN. Manajerial: Jurnal Manajemen dan Sistem Informasi, 19(2), 156-167.

Pasaribu, V. L. D. P. D. (2018). PENGARUH BIAYA PROMOSI TERHADAP PENINGKATAN PENJUALAN KARTU FLEXI PT. TELEKOMUNIKASI SELULER (TELKOMSEL) JAKARTA (Studi kasus Produk Kartu Flexi Pt. Telkomsel. Jakarta Selatan). Jurnal Pemasaran Kompetitif, 1(2).

PASARIBU, V. L. D. (2017). ANALISIS PENGARUH PROMOSI, KUALITAS PRODUK DAN DESAIN KEMASAN TERHADAP PERSEPSI MEREK YANG BERDAMPAK KEPADA KEPUTUSAN PEMBELIAN HAND AND BODY LOTION MEREK VASELINE (Studi Kasus TIP TOP Ciputat, Tangerang Selatan). Inovasi, 4(2).

Pasaribu, V. L. D., Septiani, F., Rahayu, S., Lismiatun, L., Arief, M., Juanda, A., ... \& Rahim, R. (2021). Forecast Analysis of Gross Regional Domestic Product based on the Linear Regression Algorithm Technique.

Qurbani, D., \& Pasaribu, V. L. D. (2019). Pengaruh Brand Image Dan Brand Trust Terhadap Brand Loyalty Nasabah Prudential Syariah Pada PT. Futuristik Artha Gemilang (Studi kasus di kantor cabang agensi Prudential Syariah PT. Futuristik Artha Gemilang Jakarta Selatan). Jurnal Pemasaran Kompetitif, 2(3), 121-135. 
Prianggoro, N. F., \& Sitio, A. 2019. Effect of Service Quality and Promotion On Purchase Decisions and Their Implications On Custumer Satisfaction. International Journal of Engineering Technologies and Management Research, 6(6), 51-62.

Sangadji, E.M., dan Sopiah. 2013. Prilaku Konsumen: Pendekatan Praktis Disertai Himpunan Jurnal Penelitian. Yogyakarta: Penerbit Andi.

Sangadji. 2013. Pengambilan Keputusan. Penerbit Andi: Yogyakarta.

Sejati A., S., B. 2016. Pengaruh Kualitas Produk, Kualitas Pelayanan dan Harga terhadap Keputusan Pembelian pada Starbucks. Jurnal Ilmu dan Riset Manajemen : Volume 5, Nomor 3, Maret 2016.

Simamora Bilson. 2013. Panduan Riset dan Prilaku Konsumen. PT. Granmedia Pustaka Utama : Jakarta.

Sugiyono. 2014. Metode penelitian Kuantitatif Kualitatif dan $R$ dan $D$. Penerbit CV Alfabeta: Bandung.

Sugiyono.2012. Memahami Penelitian Kualitatif. Penerbit CV Alfabeta: Bandung.

Sugiyono.2014. Metode Penelitian Kuantitatif Kualitatif $R$ dan $D$. Penerbit CV Alfabeta: Bandung.

Sumarwan Ujang. 2015. Pelaku Konsumen - Teori Dan Penerapanya Dalam Pemasaran. Ghalia Indonesia Indah.

Sumarwan Ujang. 2015. Pelaku Konsumen Teori Dan Penerapanya Dalam Pemasaran. Ghalia Indonesia Indah. 